\title{
Nimesulide derivatives reduced cell proliferation against breast and ovarian cancer: synthesis, characterization, biological assessment, and crystal structure.
}

\author{
Laila A. Jaragh-Alhadad*, Mayada S. Ali \\ Dept. of Chemistry, Kuwait University, P. O. Box 5969, Safat 13060, Kuwait \\ *Corresponding author: laila.alhadad@ku.edu.kw
}

\begin{abstract}
New nimesulide derivatives (A1-A6) were synthesized and investigated by $\mathrm{IR},{ }^{1} \mathrm{H}$ NMR, ${ }^{13} \mathrm{C}$ NMR, melting point, elemental analysis, mass spectra, and DSC analysis. Agent A3 single crystal was grown and solved in a monoclinic crystal system with Cc. Heat shock protein 27 (HSP27) and tubulin are essential cellular proteins for normal cell division and growth. In addition, these proteins are expressed highly in cancer cells. Breast cancer (SKBR3) and ovarian cancer (SKOV3) cell lines are our models for biological assessment. The data revealed that nimesulide analogs showed high cytotoxicity when treated with SKBR3 cell line ranges from $0.22 \mu \mathrm{M}$ to $12.0 \mu \mathrm{M}$, while SKOV3 cell line from $0.1 \mu \mathrm{M}$ to $16.0 \mu \mathrm{M}$. In-depth, structure-activity relationship applied to nimesulide lead structure highlights the importance of a bulk moiety in position two that reduces cell proliferation in both cell lines.
\end{abstract}

Keywords: Breast cancer; crystal structure; HSP27; nimesulide derivatives; tubulin.

\section{Introduction}

HSP27 expression is affected by stress conditions such as chemotherapy drugs (Ferms et al., 2006; Jego et al., 2013; Jaragh-Alhadad, 2018; Venugopal et al., 2019). Over-expression of HSP27 in cancer cells causes an anti-apoptotic mechanism (Arya et al., 2007; Garrido et al., 2006; Paul et al., 2010) and cancer cell survival to lethal levels (Lianos et al., 2015; Vidyasagar et al., 2012) and metastasis (Pavan et al., 2013; Zhao et al., 2012). Preventing the function of HSP27 can promote cell apoptosis. Clinically, HSP27 is expressed in tumor cells more than benign cells (Langdon et al., 1995) such as breast (Vargas-Roig et al., 1998; Kim et al., 2011) and ovarian cancers (JaraghAlhadad, 2018; Jaragh-Alhadad et al., 2021; Zhao et al., 2012). Nowadays, studies target HSP27 using OGX agents to reduce the cellular stress in both breasts (Zoubeidi \& Gleave, 2012) and the prostate (Lamoureux, 2014; Voll et al., 2014) cancers. HSP27 inhibition is an attractive therapeutic approach for future treatment because of its association with cell proliferation and survival (JaraghAlhadad 2018; Jaragh-Alhadad et al., 2021; Kaigorodova et al., 2014; Kim. et al., 2011).

Tubulin is a molecular target in cancer because it is associated with cell signaling, mitosis, movement, trafficking, and architecture (Parker et al., 2014; Philippa \& Daniel, 2013; JaraghAlhadad et al., 2021). Clinically, the docetaxel drug is used for breast cancer treatment (Lyseng- 
Williamson et al., 2005) either in a single treatment or incorporated with other agents. But some patients face drug resistance after the initial treatments (Philippa \& Daniel, 2013). Classical tubulin inhibitors cause cell cycle instability and then induce apoptosis (Li \& Sham, 2002; JaraghAlhadad et al., 2021) especially, in solid tumors (Parker et al., 2014). Overexpression of tubulin in ovarian cancer patients causes poor survival rates, so the synthesis of new agents is urgently required (Jaragh-Alhadad et al., 2021; Roque et al., 2014). This highlights tubulin as a novel therapeutic target for cancer treatments (Giannakakou et al., 2000; Jackson et al., 2007; Kanthou \& Tozer 2009 ; Parker et al., 2014).

It is a perfect strategy to treat breast and ovarian cancer cells with nimesulide derivatives to target multi-cellular proteins in one shot (Jaragh-Alhadad 2018; Jaragh-Alhadad et al., 2021). Previously in our project, agents were synthesized to target the functions of two proteins HSP27 and tubulin, and the results were potent and showed cancer cell growth inhibition (JaraghAlhadad et al., 2021). The new derivatives in the present study examined SKBR3 and SKOV3 as surrogate models, and the results were promising.

\section{Experimental}

2.1 Material and methods

All chemical analyses were tested and analyzed; at Kuwait University Research Sector Project Unit - RSPU. ${ }^{1} \mathrm{H}$ and ${ }^{13} \mathrm{C}$ nuclear magnetic resonance spectra possessed using NMR spectrophotometer Bruker, DPX 600 at $600 \mathrm{MHz}$ and $150 \mathrm{MHz}$ in DMSO and CDCL 3 . Mass spectra; had been received by the GC- MS DFS-Thermo spectrometer, while IR spectra from a Jasco 6300 FT-IR. The DSC curves were recorded on Netzsch DSC 204F1 Phoenix 240-12-0274L. The single-crystal X-ray diffraction analysis was solved and refined using the Bruker SHELXTL software package.

Nimesulide derivatives were designed and synthesized in our laboratory. All chemicals and solvents used for the synthesis were commercially available and were used directly without further preparation.

\subsection{Single-crystal data collection and structure refinement}

The crystal structure of A3 was grown by dissolving $15.0 \mathrm{mg}$ of it in $1 \mathrm{ml}$ of hot ethanol. Parafilm covered the solution, including holes to allow slow evaporation. A crystal was grown and diffracted within a week by the Bruker SHELXTL Software Package-narrow-frame algorithm. The multi-Scan method (SADABS) determined the data of the absorption. The ratio of minimum/ maximum apparent transmission was equal to 0.571 . The calculated minimum and maximum transmission coefficients (based on crystal size) are 0.1970 and 0.5840 . 
2.3 Synthesis of N-(4-amino-2-((2,5-dimethoxybenzyl)oxy)phenyl)methane-sulfonamide and its derivatives.

2-Amino-5-nitrophenol (0.154 g; $1 \mathrm{mmol})$ used as our starting material in (Scheme 1), mixed with 2-(chloromethyl)-1,4-dimethoxybenzene $(0.186 \mathrm{~g} ; 1 \mathrm{mmol})$ with $\mathrm{K}_{2} \mathrm{CO}_{3}(0.138 \mathrm{~g} ; 1 \mathrm{mmol})$ and DMF overnight. In the next step, both sodium hydride $(0.12 \mathrm{~g} ; 5 \mathrm{mmol})$ and methane sulfonyl chloride $(0.114 \mathrm{~g} ; 1 \mathrm{mmol})$ was added to compound (A) in dry DMF at room temperature to obtain compound (B) within an hour. Then, $\mathrm{FeCl}_{3}$ was added (0.648 g; $\left.4 \mathrm{mmol}\right)$ with DMF and water and kept stirring for 15 minutes. Then, adding $\mathrm{Zn}(6.5 \mathrm{~g} ; 10 \mathrm{mmol})$ to the solution to reduce the nitro group to an amine group to obtain compound (C). Then, different moieties such as 4-bromobenzoyl chloride, 4-iodobenzoyl chloride, and 4-methoxybenzoyl chloride were added to compound (C) (1 mmol) with $\mathrm{K}_{2} \mathrm{CO}_{3}$ and 1:4 dioxane to obtain the final compounds A1-A3. Synthesis steps carried at room temperature, ligands were precipitated, filtered off, and recrystallized from hot ethanol. Specifically, A3 was grown as a single crystal diffracted.

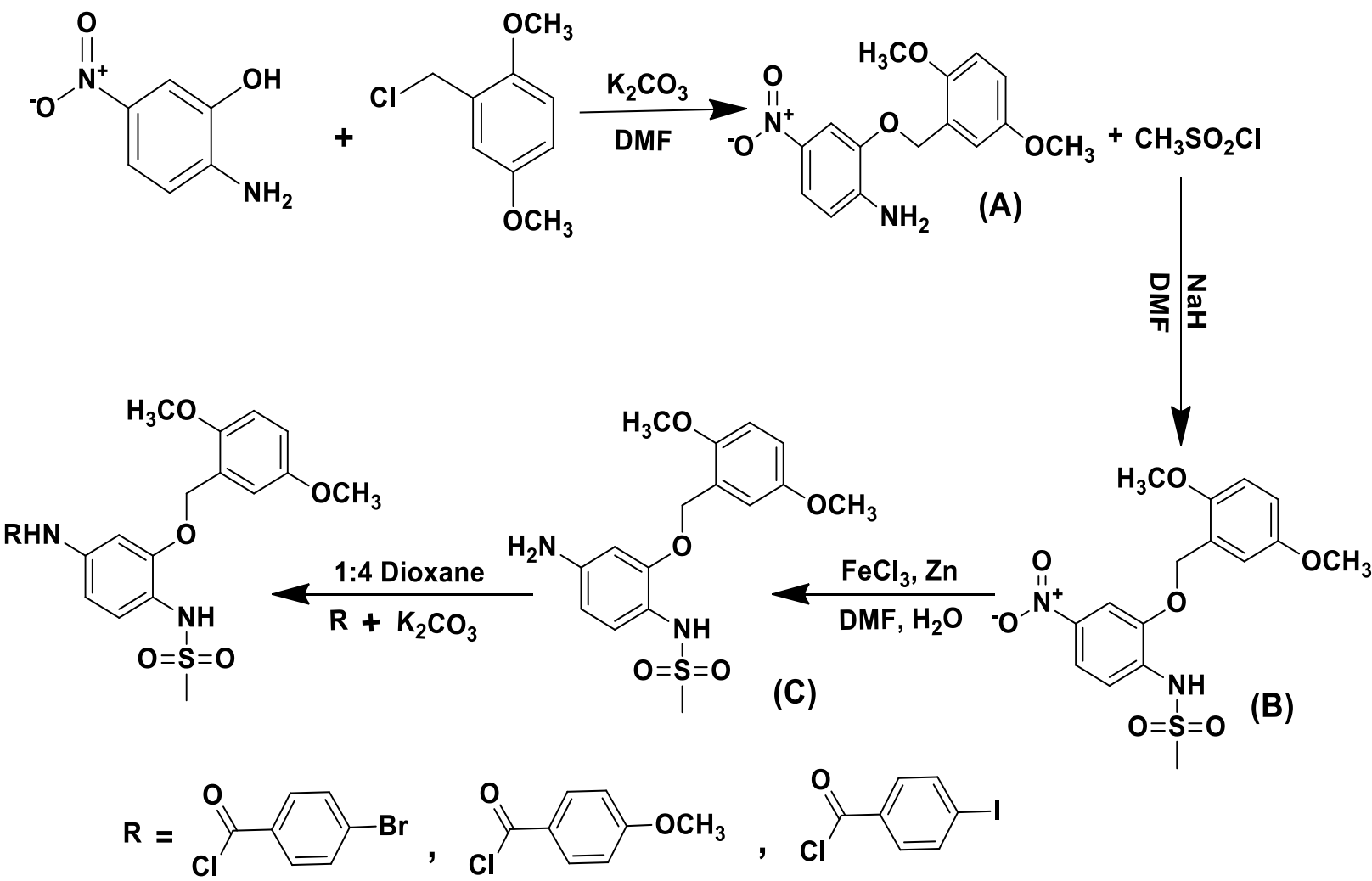

(A1)

(A2)

(A3)

Scheme 1. Synthesis of N-(4-amino-2-((2, 5-dimethoxy benzyl)oxy)phenyl)methane sulfonamide and its derivatives. 
2.4 Synthesis of N-(4-amino-2-((2,5-dimethoxy benzyl)oxy) phenyl)-1,1,1-trifluoro methane sulfonamide and its derivatives.

Step one in scheme 1 is the same. The second step, methane sulfonyl chloride; is replaced by the compound trifluoromethane sulfonyl chloride until we get compound (D), followed by a methylation step with methyl iodide $(0.141 \mathrm{~g} ; 1 \mathrm{mmol})$, sodium hydride $(0.12 \mathrm{~g} ; 5 \mathrm{mmol})$, and DMF to produce compound $(\mathrm{E})$. Then, reducing the nitro group to the amine group to obtain compound (F). Different moieties such as 2-naphthoyl chloride, 3,4-dimethoxybenzoyl chloride, and 4-iodobenzoyl chloride added with (1 mmol), $\mathrm{K}_{2} \mathrm{CO}_{3}, 1: 4$ dioxane were substituted on compound (F) (1 mmol) to obtain the final agents A4-A6 (Scheme 2).
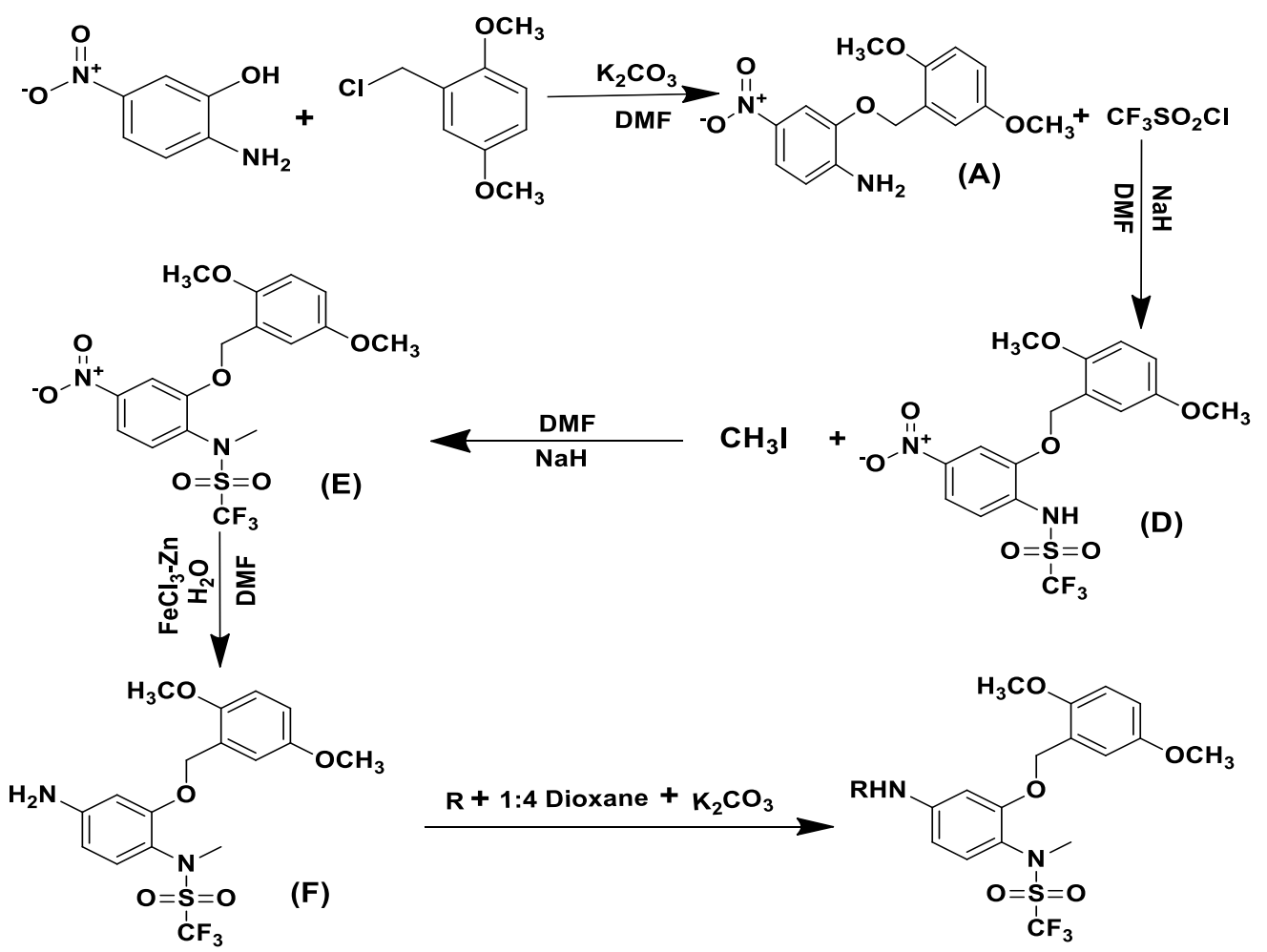<smiles>COc1ccc(C(=O)Cl)cc1OC</smiles>

(A4)<smiles>O=C(Cl)c1ccc(I)cc1</smiles>

(A5)<smiles>O=C(Cl)c1ccc2ccccc2c1</smiles>

(A6)

Scheme 2. Synthesis of N-(4-amino-2-((2,5-dimethoxy benzyl) oxy) phenyl)-1,1,1-trifluoro-Nmethylmethanesulfonamide and its derivatives.

\subsection{Biological studies: cell culture and cell viability}

Breast cancer cell line SKBR3 and ovarian cancer cell line SKOV3 were Breast cancer (SKBR3) and ovarian cancer (SKOV3) cell lines from ATCC (Rockville, MD). RPMI1640 medium 
supplemented with $10 \%$ fetal bovine serum (FBS), used to maintain the cells, two mmol/L Lglutamine; $1 \mathrm{mmol} / \mathrm{L}$ sodium pyruvate, $100 \mathrm{U} / \mathrm{mL}$ penicillin-streptomycin. FBS heated to inactivate it for $30 \mathrm{~min}$ in a $56{ }^{\circ} \mathrm{C}$ water bath before use. Cell cultures were grown $5 \% \mathrm{CO} 2$ incubator (Bridgeport N.J.). MTT assay was applied using 3-(4,5-dimethylthiazol-2-yl)-2,5diphenyl-2H- tetrazolium bromide assay in six replicates.

Cells were grown in RPMI1640 medium in 96-well, flat-bottomed plates for $24 \mathrm{~h}$; and were exposed to various concentrations of the agents dissolved in DMSO (final concentration $\leq 0.1 \%$ ) in media for $48 \mathrm{hr}$. The medium was removed, replaced by $200 \mu \mathrm{L}$ of $0.5 \mathrm{mg} / \mathrm{ml}$ of 3-(4,5dimethylthiazol-2-yl)-2,5-diphenyl-2H-tetrazolium bromide in new media followed by incubation for two hrs. Supernatants; were removed, followed by DMSO addition $200 \mu \mathrm{L} / w e l l$. The plate reader; was used to determine the absorbance at $570 \mathrm{~nm}$. Statistical and graphical information was determined using GraphPad Prism software (GraphPad Software Incorporated) and Microsoft Excel (Microsoft Corporation). $\mathrm{IC}_{50}$ values were determined using nonlinear regression analysis.

\section{Results and discussion}

In the present study, six nimesulide derivatives were designed, synthesized, and characterized. Table 1 summarizes the agents' chemical formulae, physical properties, elemental analysis, and molecular weight obtained from mass spectra. Anticancer agents were characterized by IR, ${ }^{1} \mathrm{H} \mathrm{NMR},{ }^{13} \mathrm{C}$ NMR, melting point, and DSC analysis. Molecular weight was confirmed using the GC-MS technique. Additionally, agent A3 single crystal was obtained and crystallographically solved as shown in (Structure 1). Furthermore, the biological assessment targeting both HSP27 and tubulin proteins against breast and ovarian cancer cell lines showed promising anticancer activities based on specific essential bulk moieties.

Table 1. Molecular weight and elemental analysis of (A1-A6) agents.

\begin{tabular}{|c|c|c|c|c|c|c|c|}
\hline $\begin{array}{l}\text { Compound, } \\
\text { Empirical formula }\end{array}$ & $\begin{array}{l}\text { M.W., m/e } \\
\text { Calcd. } \\
\text { (Found) }\end{array}$ & Color & $\begin{array}{l}\text { M.P., }{ }^{\circ} \\
\text { C }\end{array}$ & $\begin{array}{l}\text { C\% Calcd. } \\
\text { (Found) }\end{array}$ & $\begin{array}{l}\mathrm{H} \% \\
\text { Calcd. } \\
\text { (Found) }\end{array}$ & $\begin{array}{l}\text { N\% } \\
\text { Calcd. } \\
\text { (Found) }\end{array}$ & $\begin{array}{l}\text { S\% Calcd. } \\
\text { (Found) }\end{array}$ \\
\hline $\begin{array}{l}\mathrm{A} 1 \\
\mathrm{C}_{23} \mathrm{H}_{23} \mathrm{BrN}_{2} \mathrm{O}_{6} \mathrm{~S}\end{array}$ & $\begin{array}{l}535.41 \\
(535.02)\end{array}$ & $\begin{array}{l}\text { Pale } \\
\text { yellow }\end{array}$ & $\begin{array}{l}218- \\
220\end{array}$ & $\begin{array}{l}51.60 \\
(51.64)\end{array}$ & $\begin{array}{l}4.33 \\
(4.31)\end{array}$ & $\begin{array}{l}5.23 \\
(5.25)\end{array}$ & $\begin{array}{l}5.99 \\
(5.95)\end{array}$ \\
\hline $\begin{array}{l}\mathrm{A} 2 \\
\mathrm{C}_{24} \mathrm{H}_{26} \mathrm{~N}_{2} \mathrm{O}_{7} \mathrm{~S}\end{array}$ & $\begin{array}{l}486.54 \\
(486.12)\end{array}$ & Paige & $\begin{array}{l}231- \\
234\end{array}$ & $\begin{array}{l}59.25 \\
(59.24)\end{array}$ & $\begin{array}{l}5.39 \\
(5.40)\end{array}$ & $\begin{array}{l}5.76 \\
(5.75)\end{array}$ & $\begin{array}{l}6.59 \\
(6.57)\end{array}$ \\
\hline $\begin{array}{l}\mathrm{A} 3 \\
\mathrm{C}_{23} \mathrm{H}_{23} \mathrm{IN}_{2} \mathrm{O}_{6} \mathrm{~S}\end{array}$ & $\begin{array}{l}582.41 \\
(582.39)\end{array}$ & Paige & $\begin{array}{l}225- \\
227\end{array}$ & $\begin{array}{l}47.43 \\
(47.42)\end{array}$ & $\begin{array}{l}3.98 \\
(3.96)\end{array}$ & $\begin{array}{l}4.81 \\
(4.80)\end{array}$ & $\begin{array}{l}5.51 \\
(5.52)\end{array}$ \\
\hline $\begin{array}{l}\mathrm{A} 4 \\
\mathrm{C}_{26} \mathrm{H}_{27} \mathrm{~F}_{3} \mathrm{~N}_{2} \mathrm{O}_{8} \mathrm{~S}\end{array}$ & $\begin{array}{l}584.56 \\
(585.09)\end{array}$ & $\begin{array}{l}\text { Pale } \\
\text { yellow }\end{array}$ & $\begin{array}{l}151- \\
153\end{array}$ & $\begin{array}{l}53.42 \\
(53.40)\end{array}$ & $\begin{array}{l}4.66 \\
(4.64)\end{array}$ & $\begin{array}{l}4.79 \\
(4.78)\end{array}$ & $\begin{array}{l}5.49 \\
(5.47)\end{array}$ \\
\hline $\begin{array}{l}\mathrm{A} 5 \\
\mathrm{C}_{24} \mathrm{H}_{22} \mathrm{~F}_{3} \mathrm{IN}_{2} \mathrm{O}_{6} \mathrm{~S}\end{array}$ & $\begin{array}{l}650.41 \\
(651.03)\end{array}$ & Paige & $\begin{array}{l}175- \\
177\end{array}$ & $\begin{array}{l}44.32 \\
(44.34)\end{array}$ & $\begin{array}{l}3.41 \\
(3.42)\end{array}$ & $\begin{array}{l}4.31 \\
(4.33)\end{array}$ & $\begin{array}{l}4.93 \\
(4.92)\end{array}$ \\
\hline $\begin{array}{l}\mathrm{A} 6 \\
\mathrm{C}_{28} \mathrm{H}_{25} \mathrm{~F}_{3} \mathrm{~N}_{2} \mathrm{O}_{6} \mathrm{~S}\end{array}$ & $\begin{array}{l}574.57 \\
(575.16)\end{array}$ & $\begin{array}{l}\text { Pale } \\
\text { yellow }\end{array}$ & $\begin{array}{l}187- \\
188\end{array}$ & $\begin{array}{l}58.53 \\
(58.49)\end{array}$ & $\begin{array}{l}5.39 \\
(5.36)\end{array}$ & $\begin{array}{l}4.88 \\
(4.84)\end{array}$ & $\begin{array}{l}5.58 \\
(5.53)\end{array}$ \\
\hline
\end{tabular}


3.1 Crystal structure of N-(3-((2,5-dimethoxy benzyl) oxy)-4-(methylsulfonamido) phenyl)-4iodobenzamide (A3).

The asymmetric unit of A3 contains two molecules having the same chemical structure but different conformations. One conformer shows all aromatic fragments lying almost in the same plane. At the same time, in the other conformer, the 4-iodophenyl moiety is oriented perpendicular $\left(80.8^{\circ}\right)$ to the plane of the other two phenyl moieties. The different conformational features of these two structures are demonstrated in (Figure 1) where both conformers are overlaid. The crystal packing showed conformers intercalated together, as shown in supporting information. The crystal packing is stable by efficient H-bonding and non-bonding interactions among adjacent molecules. In addition to $\mathrm{p}-\mathrm{p}$ interactions among the same types of conformers, there are $\mathrm{C}-\mathrm{H}$...p interactions between the iodophenyl moieties of different conformations in the crystal network (Figure 2) (AlAzmi and Mickey 2020).

N-(3-((2,5-dimethoxybenzyl)oxy)-4-(methylsulfonamido)phenyl)-4-iodobenzamide, (A3) is a clear colorless block with the formula $\mathrm{C}_{23} \mathrm{H}_{23} \mathrm{IN}_{2} \mathrm{O}_{6} \mathrm{~S}$ and has a molecular weight of 582.39 (Structure 1). It belongs to a monoclinic system with $\mathrm{C} 1 \mathrm{c} 1$ space group, as shown in (Table 2). The estimated cell parameters are: $a=54.42(2) \AA, b=4.98(3) \AA, c=18.02(10) \AA, \alpha=90^{\circ}, \beta=$ $108.17(3)^{\circ}, \gamma=90^{\circ}$. The O4-C16 bond length $(1.19 \AA)$ is typical of a delocalized $\pi$ electron system (1.20 $\AA$ ). The bond length of S2-O11 and S2-O12 are $(1.413 ; 1.435 \AA)$, which are within the values of the double bond. The bond length of N1-C15 and N2-C12 are almost equal (1.41 and $1.40 \AA$ ), while the bond length of I1-C20 is $2.03 \AA$ (Table 3).

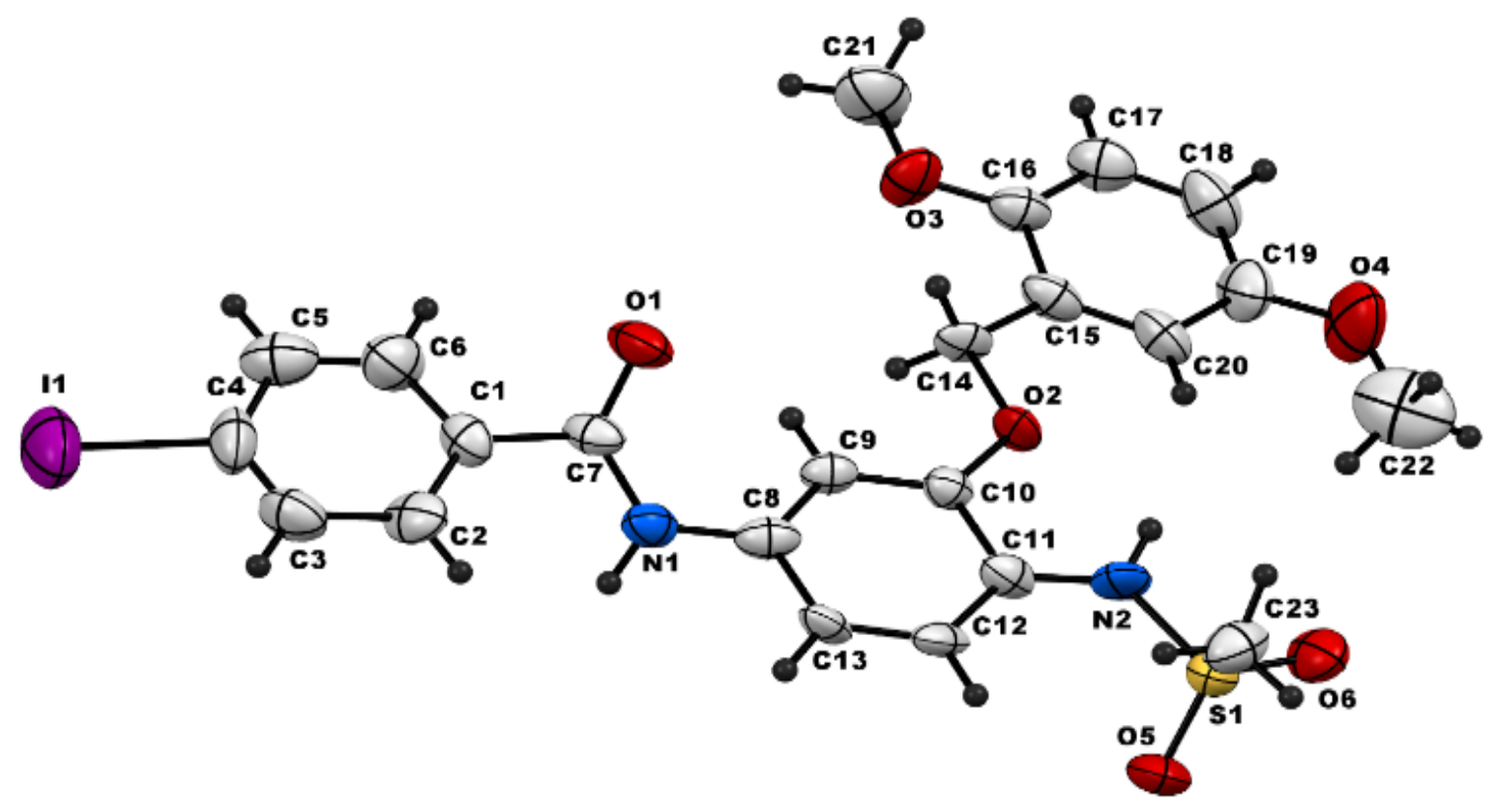

Structure 1. X-ray crystal structure of agent A3. 


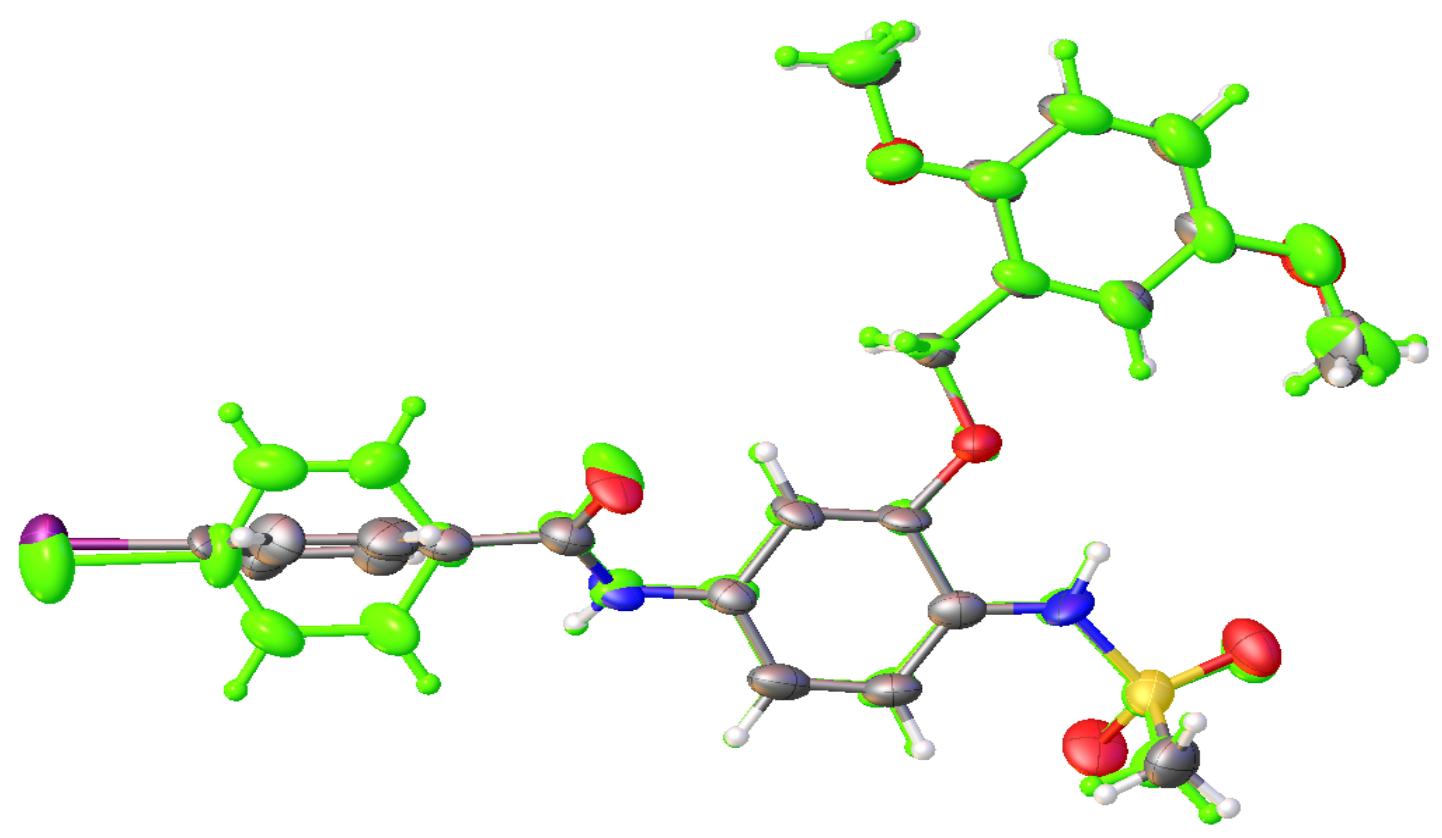

Fig. 1. Crystal structure of A3 molecule showing both conformers overlaid to each other. The green-colored conformer has all phenyl groups lying in the same plane, and the multicolored conformer is the structure with 4-iodophenyl fragment oriented almost perpendicular to the plane of the other two phenyl moieties.

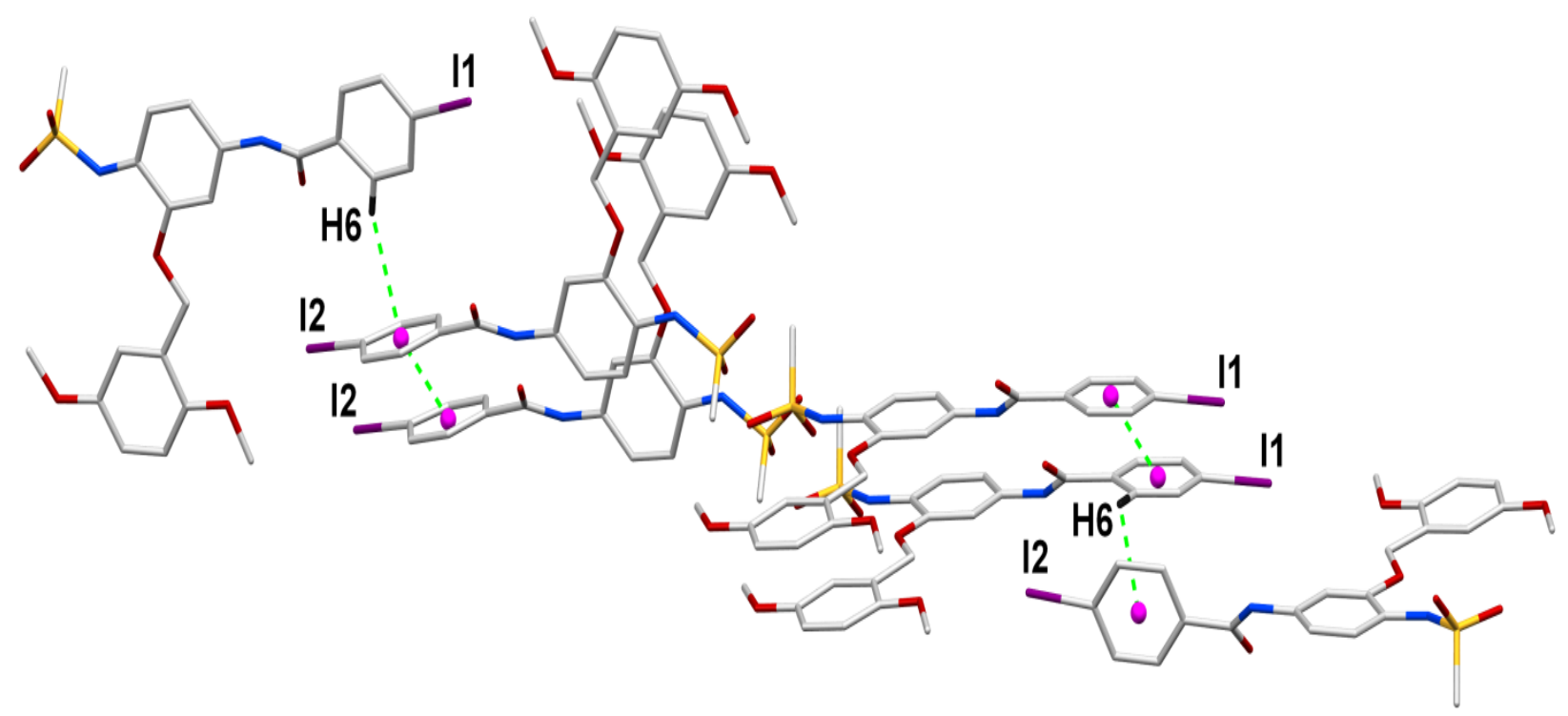

Fig. 2. The Crystal network of A3 molecules showed p-p interactions between 4-iodophenyl moieties of similar conformers and $\mathrm{C}-\mathrm{H}$...p interactions between the iodophenyl moieties of different conformers. 
Table 2. Data collection and refinement for A3.

\begin{tabular}{|c|c|}
\hline Identification code & A3 \\
\hline Empirical formula & $\mathrm{C}_{23} \mathrm{H}_{23} \mathrm{IN}_{2} \mathrm{O}_{6} \mathrm{~S}$ \\
\hline Formula weight & 582.39 \\
\hline Temperature/K & $296(2)$ \\
\hline Crystal system & monoclinic \\
\hline Space group & $\mathrm{Cc}$ \\
\hline $\mathrm{a} / \AA$ & $54.418(3)$ \\
\hline $\mathrm{b} / \AA \AA$ & $4.9805(3)$ \\
\hline $\mathrm{c} / \AA$ & $18.0143(11)$ \\
\hline$\alpha /^{\circ}$ & 90 \\
\hline$\beta /{ }^{\circ}$ & $108.145(3)$ \\
\hline$\gamma /{ }^{\circ}$ & 90 \\
\hline Volume $/ \AA^{3}$ & $4639.6(5)$ \\
\hline $\mathrm{Z}$ & 8 \\
\hline$\rho_{\text {calc }} \mathrm{g} / \mathrm{cm}^{3}$ & 1.668 \\
\hline$\mu / \mathrm{mm}^{-1}$ & 12.057 \\
\hline $\mathrm{F}(000)$ & 2336.0 \\
\hline Crystal size $/ \mathrm{mm}^{3}$ & $0.2 \times 0.15 \times 0.05$ \\
\hline Radiation & $\mathrm{CuK} \alpha(\lambda=1.54178)$ \\
\hline $2 \Theta$ range for data collection $/{ }^{\circ}$ & 9.822 to 130.102 \\
\hline Index ranges & $-63 \leq \mathrm{h} \leq 63,0 \leq \mathrm{k} \leq 5,-20 \leq 1 \leq 20$ \\
\hline Reflections collected & 6123 \\
\hline Independent reflections & $6123\left[\mathrm{R}_{\text {int }}=?, \mathrm{R}_{\text {sigma }}=0.0936\right]$ \\
\hline Data/restraints/parameters & $6123 / 2 / 602$ \\
\hline Goodness-of-fit on $\mathrm{F}^{2}$ & 1.049 \\
\hline Final $R$ indexes $[\mathrm{I}>=2 \sigma(\mathrm{I})]$ & $\mathrm{R}_{1}=0.0832, \mathrm{wR}_{2}=0.2273$ \\
\hline Final R indexes [all data] & $\mathrm{R}_{1}=0.1012, \mathrm{wR}_{2}=0.2435$ \\
\hline Largest diff. peak/hole / e $\AA^{-3}$ & $2.22 /-0.94$ \\
\hline Flack parameter & $0.278(7)$ \\
\hline
\end{tabular}


Table 3. Bond lengths $(\AA)$ and bond angles for A3.

\begin{tabular}{|c|c|c|c|}
\hline Bond & Length, $\AA$ & Bond & Length, $\AA$ \\
\hline S1-O5 & $1.413(18)$ & S2-O12 & $1.435(17)$ \\
\hline S1-N1 & $1.626(14)$ & O3-C9 & $1.42(3)$ \\
\hline N1-C15 & $1.41(3)$ & N2-C12 & $1.41(3)$ \\
\hline O4-C16 & $1.19(3)$ & O3-C10 & $1.41(3)$ \\
\hline I1-C20 & $2.03(2)$ & S1-C23 & $1.74(3)$ \\
\hline O1-C1 & $1.24(3)$ & O2-C4 & Angle, ${ }^{\circ}$ \\
\hline Bond & Angle, ${ }^{\circ}$ & Bond & $123.9(17)$ \\
\hline I1-C20-C21 & $118.0(15)$ & C16-N2-C12 & $128.2(14)$ \\
\hline C12-N2-H & 118.0 & C15-N1-S1 & $107.2(11)$ \\
\hline N1-S1-O6 & $108.3(9)$ & N1-S1-O5 & $116.2(14)$ \\
\hline N1-S1-C23 & $106.8(12)$ & C10-C3-C9 & $121 .(3)$ \\
\hline C1-O1-C7 & $115 .(2)$ & C4-O2-C8 & $16-O 3$ \\
\hline C9-O3-C10 & $116.2(14)$ & & \\
\hline
\end{tabular}

3.2 Nuclear magnetic resonance $\left({ }^{1} \mathrm{H} \mathrm{NMR}\right.$ and $\left.{ }^{13} \mathrm{C} \mathrm{NMR}\right)$.

The ${ }^{1} \mathrm{H}$ NMR spectra of (A1-A6); were tested in DMSO at $25^{\circ} \mathrm{C}$ (Table 4). The spectra of agents A1-A2 (Figures S1 \& S2) showed the same signals at 2.86-2.88, 5.09, 3.76-3.73, 7.93-6.88 ppm due to spectrum of $\mathrm{CH}_{3}$ (sulphonyl), $\mathrm{CH}_{2}, \mathrm{OCH}_{3}$, and $\mathrm{Ar}-\mathrm{H}$ while signals at 10.37-10.14 and 9.01$8.97 \mathrm{ppm}$ due to the peak of NH (sulphonyl) and $\mathrm{NH}$ (carbonyl) respectively. While the spectra of agents A4-A6 (Figures S3-S5) show signals at 3.36-3.40 ppm due to $\mathrm{CH}_{3}$ (nitrogen) and only one band for NH (carbonyl) at 10.06, 7.97, and $10.04 \mathrm{ppm}$. On the other hand, the ${ }^{13} \mathrm{C} \mathrm{NMR}$ spectra (Figures S6-S10) showed peaks at 164.49, 153.17, 138.40, 105.21, and 66.33 ppm due to $\mathrm{C}=\mathrm{O}, \mathrm{C}$ $\mathrm{O}, \mathrm{C}-\mathrm{N}, \mathrm{C}=\mathrm{C}$, and $\mathrm{CH}_{3}$. In the $1 \mathrm{H}$ NMR spectra for Ligands (A1-A6), $\mathrm{NH}$ (carbonyl) peak showed a signal for one proton, which is a piece of evidence that the reaction occurred and $\mathrm{HCl}$ left proved previously in (Jaragh-Alhadad et al., 2021). 
Table 4. ${ }^{1} \mathrm{H}$ and ${ }^{13} \mathrm{C}$ NMR signals of the agents.

\begin{tabular}{|c|c|c|c|c|c|c|}
\hline Agent & $\begin{array}{l}\mathrm{NH}(\mathrm{S}) \\
\mathrm{NH}(\mathrm{C})\end{array}$ & $\mathrm{Ar}-\mathrm{H}$ & $\mathrm{CH}_{2}$ & $\mathrm{OCH}_{3}$ & $\begin{array}{l}\mathrm{CH}_{3}(\mathrm{~S}) \\
\mathrm{CH}_{3}(\mathrm{~N})\end{array}$ & ${ }^{13} \mathrm{C}$ signals \\
\hline A1 & $\begin{array}{c}10.37(\mathrm{~s}, 1 \mathrm{H}) \\
9.01(\mathrm{~s}, 1 \mathrm{H})\end{array}$ & $\begin{array}{c}7.93-6.88 \\
(\mathrm{~m}, 10 \mathrm{H})\end{array}$ & $\begin{array}{c}5.09 \\
(\mathrm{~s}, 2 \mathrm{H})\end{array}$ & $\begin{array}{c}3.76-3.73 \\
(\mathrm{~d}, 6 \mathrm{H})\end{array}$ & $\begin{array}{c}2.88(\mathrm{~s}, 3 \mathrm{H}) \\
---\end{array}$ & $\begin{array}{c}164.49(\mathrm{C}=\mathrm{O}) \\
153.17(\mathrm{C}-\mathrm{O}) \\
138.40(\mathrm{C}-\mathrm{N}) \\
105.21(\mathrm{C}=\mathrm{C}) \\
66.33\left(\mathrm{CH}_{3}\right)\end{array}$ \\
\hline A2 & $\begin{array}{c}10.14(\mathrm{~s}, 1 \mathrm{H}) \\
8.97(\mathrm{~s}, 1 \mathrm{H})\end{array}$ & $\begin{array}{c}7.97-6.87 \\
(\mathrm{~m}, 10 \mathrm{H})\end{array}$ & $\begin{array}{c}5.08 \\
(\mathrm{~s}, 2 \mathrm{H})\end{array}$ & $\begin{array}{c}3.84-3.73 \\
(\mathrm{t}, 9 \mathrm{H})\end{array}$ & $\begin{array}{c}2.86(\mathrm{~s}, 3 \mathrm{H}) \\
---\end{array}$ & $\begin{array}{c}164.85(\mathrm{C}=\mathrm{O}) \\
153.17(\mathrm{C}-\mathrm{O}) \\
138.90(\mathrm{C}-\mathrm{N}) \\
105.08(\mathrm{C}=\mathrm{C}) \\
64.87\left(\mathrm{CH}_{3}\right)\end{array}$ \\
\hline A4 & $10.06(\mathrm{~s}, 1 \mathrm{H})$ & $\begin{array}{c}7.80-6.89 \\
(\mathrm{~m}, 9 \mathrm{H})\end{array}$ & $\begin{array}{c}5.13 \\
(\mathrm{~s}, 2 \mathrm{H})\end{array}$ & $\begin{array}{c}3.86-3.73 \\
(\mathrm{~m}, 12 \mathrm{H})\end{array}$ & $3.36(\mathrm{~s}, 3 \mathrm{H})$ & $\begin{array}{c}165.13(\mathrm{C}=\mathrm{O}) \\
154.81(\mathrm{C}-\mathrm{O}) \\
141.74(\mathrm{C}-\mathrm{N}) \\
105.21(\mathrm{C}=\mathrm{C}) \\
65.04\left(\mathrm{CH}_{3}\right)\end{array}$ \\
\hline A5 & $\begin{array}{c}--- \\
7.97(\mathrm{~s}, 1 \mathrm{H})\end{array}$ & $\begin{array}{l}7.84-6.84 \\
(\mathrm{~m}, 10 \mathrm{H})\end{array}$ & $\begin{array}{c}5.14 \\
(\mathrm{~s}, 2 \mathrm{H})\end{array}$ & $\begin{array}{l}3.82-3.72 \\
(\mathrm{t}, 6 \mathrm{H})\end{array}$ & $3.40(\mathrm{~s}, 3 \mathrm{H})$ & $\begin{array}{c}165.23(\mathrm{C}=\mathrm{O}) \\
156.01(\mathrm{C}-\mathrm{O}) \\
140.20(\mathrm{C}-\mathrm{N}) \\
105.69(\mathrm{C}=\mathrm{C}) \\
67.29\left(\mathrm{CH}_{3}\right)\end{array}$ \\
\hline A6 & $10.04(\mathrm{~s}, 1 \mathrm{H})$ & $\begin{array}{c}8.59-6.89 \\
(\mathrm{~m}, 13 \mathrm{H})\end{array}$ & $\begin{array}{c}5.15 \\
(\mathrm{~s}, 2 \mathrm{H})\end{array}$ & $\begin{array}{c}3.80-3.56 \\
(\mathrm{t}, 6 \mathrm{H})\end{array}$ & $3.36(\mathrm{~d}, 3 \mathrm{H})$ & $\begin{array}{l}165.81(\mathrm{C}=\mathrm{O}) \\
154.87(\mathrm{C}-\mathrm{O}) \\
141.65(\mathrm{C}-\mathrm{N}) \\
105.25(\mathrm{C}=\mathrm{C}) \\
66.33\left(\mathrm{CH}_{3}\right)\end{array}$ \\
\hline
\end{tabular}

\subsection{Infrared spectra analysis}

The major IR bands of agents A1-A6; are listed in (Table 5); their spectrum showed bands at (3276-3382), (1641-1658), (1592-1604), (1216-1232), (755-761), 755 and $748 \mathrm{~cm}^{-1}$ attributed to $v(\mathrm{NH}), v(\mathrm{C}=\mathrm{O}), v(\mathrm{C}-\mathrm{N}), v(\mathrm{C}-\mathrm{O}), v(\mathrm{C}-\mathrm{Br})$ and $v(\mathrm{C}-\mathrm{I})$ respectively (Figures $\mathrm{S} 11-\mathrm{S} 15)$. The appearance of $\left(\mathrm{SO}_{2}\right)$ bands at $1382 \mathrm{~cm}^{-1}$ due to $v_{3}$ asymmetric stretching $\left(1174-1184 \mathrm{~cm}^{-1}\right)$ for $v_{1}$, and the $\mathrm{v}_{2}$ bending region at $507-512 \mathrm{~cm}^{-1}$ (Song et al., 2005). 
Table 5. IR spectral data $\left(\mathrm{cm}^{-1}\right)$ of agent A1-A6.

\begin{tabular}{|l|l|l|l|l|l|l|}
\hline Agent & $v(\mathrm{NH})$ & $v(\mathrm{C}=\mathrm{O})$ & $v(\mathrm{C}-\mathrm{N})$ & $v(\mathrm{C}-\mathrm{O})$ & $v\left(\mathrm{SO}_{2}\right)$ & $v(\mathrm{C}-\mathrm{X})$ \\
\hline A1 & $\begin{array}{l}3345 \mathrm{br} \\
3276 \mathrm{br}\end{array}$ & $1641 \mathrm{~s}$ & $1604 \mathrm{~m}$ & $1216 \mathrm{~m}$ & $\begin{array}{c}1382 \mathrm{w}, 1184 \mathrm{w}, \\
512 \mathrm{~m}\end{array}$ & $755 \mathrm{~m}$ \\
\hline A2 & $3278 \mathrm{br}$ & $1641 \mathrm{~s}$ & $1604 \mathrm{~s}$ & $1218 \mathrm{~m}$ & $\begin{array}{c}1382 \mathrm{~m}, 1182 \mathrm{w}, \\
514 \mathrm{~m}\end{array}$ & -- \\
\hline A4 & $3282 \mathrm{br}$ & $1650 \mathrm{~m}$ & $1596 \mathrm{~m}$ & $1232 \mathrm{~m}$ & $\begin{array}{c}1382 \mathrm{~m}, 1184 \mathrm{w}, \\
507 \mathrm{w}\end{array}$ & -- \\
\hline A5 & $3324 \mathrm{br}$ & $1658 \mathrm{~s}$ & $1592 \mathrm{~s}$ & $1216 \mathrm{~m}$ & $\begin{array}{c}1390 \mathrm{~s}, 1180 \mathrm{~m}, \\
509 \mathrm{~m}\end{array}$ & $748 \mathrm{w}$ \\
\hline A6 & $3316 \mathrm{br}$ & $1654 \mathrm{~s}$ & $1602 \mathrm{~m}$ & $1218 \mathrm{w}$ & $\begin{array}{c}1390 \mathrm{~s}, 1174 \mathrm{~m}, \\
507 \mathrm{w}\end{array}$ & -- \\
\hline
\end{tabular}

$\mathrm{X}=\mathrm{Br}, \mathrm{I}$

\subsection{DSC Thermal analysis.}

DSC provides the most direct, comprehensive approach for monitoring and interpreting binding interactions involving biological macromolecules. DSC is generally used to measure the partial molar heat capacity over a temperature range of approximately $80{ }^{\circ} \mathrm{C}$. If a ligand binds to the protein native state, the temperature at which the protein-ligand complex denatures will be higher than the temperature at which the free protein unfolds. DSC thus provides a direct measure of whether ligand binding to a protein is stabilizing or destabilizing. Our agents showed different behaviors in the DSC (Figures S16-S20). The sharp endothermic peaks vary between $150-250^{\circ} \mathrm{C}$, and broad exothermic peaks vary between $300-450^{\circ} \mathrm{C}$. The first endothermic peak corresponds to the melting of the Agents, while the second peak represents its decomposition.

\subsection{Mass spectra analysis of agent A1-A6.}

The mass spectrum of agent A1 (Figure S21) showed a molecular peak at $\mathrm{m} / \mathrm{z}=535.02$ (Calcd. 535.41). The other positive ions give peaks at 456 (5\%), 184 (20\%), 151 (100\%), 121 (75\%), 91 (15\%) mass numbers. The spectrum of agent A2 (Figure S22) showed a signal at $\mathrm{m} / \mathrm{z}=486.12$ (Calcd. 486.54) with 25\% abundance. The peaks at 407, 375, 151, 135,121, and 77 are due to the degradation of its species. On the other hand, the MS of agent A4 (Figure S23) represented fragmentation patterns corresponding to the degradation, the first peak at 585.09 (Calcd. 584.56) in agreement with the molecular ion of the agent, and the peaks appeared at $585(17 \%), 451,236$ (5\%), 151 (100\%), $121(20 \%)$ and 69 (10\%) mass numbers. The spectrum of agent A5 (Figure S24) displayed multi peaks representing sequential degradation, the molecular peak at $\mathrm{m} / \mathrm{z}=651$ (Calcd. 650.41) with 10\% abundance. Also, there are peaks at 230, 151, 121, and 91 mass numbers. Agent A6 MS spectra (Figure S25) showed a peak at 575 with abundance (20\%) agreement with calculated molecular weight (574.57), and the other peaks at 441, 151, 121, and 91 represented degradations of the compound. The common ion peak appeared in all spectra at $\mathrm{m} / \mathrm{e}=151$ (calcd 154.12), representing the stable species $\left[\mathrm{C}_{6} \mathrm{H}_{6} \mathrm{~N}_{2} \mathrm{O}_{3}\right]$ with $100 \%$ abundance. 
Nimesulide derivatives reduced cell proliferation against breast and ovarian cancer: synthesis, characterization, biological assessment, and crystal structure.

\subsection{Structure-activity relationship and the biological assessment of the agents}

New derivatives of nimesulide targeted both HSP27 and tubulin functions. The new agents in group I and group II inhibited women's cancers cell proliferation at sub-molar levels and showed potent anti-cancer activity (Table 6). In group I, moieties on positions $1,2 \& 3$ are fixed, while different moieties are substituted into position 4 (moiety A1: 4-bromophenyl; A2: 4methoxyphenyl; A3: 4-iodophenyl). The data showed that the $\mathrm{IC}_{50 \mathrm{~S}}$ of cell growth inhibition in breast cancer (SKBR3) cell line of agents A1, A2 \& A3 ranges from $10.0 \mu \mathrm{M}$ to $11.0 \mu \mathrm{M}$. While, in the ovarian cancer (SKOV3) cell line, agents A1, A2 \& A3 range from $5.0 \mu \mathrm{M}$ to $16.0 \mu \mathrm{M}$. These agents showed promising anticancer activity in breast and ovarian cancer due to the essential bulk group in position four.

In group II, moieties on positions $1,2 \& 3 \mathrm{kept}$ the same while different moieties substituted into position 4 (moiety A4: 3,4-dimethoxyphenyl; A5: 4-iodophenyl; A6: 4-napthayl). The data revealed that the $\mathrm{IC}_{50} \mathrm{~S}$ of cell growth inhibition in breast cancer cell line (SKBR3) of agents A4, A5 \& A6 range from $0.22 \mu \mathrm{M}$ to $0.55 \mu \mathrm{M}$. While, in ovarian cancer cell-line (SKOV3), agents A4, A5 \& A6 range from $0.19 \mu \mathrm{M}$ to $0.30 \mu \mathrm{M}$. Group II moieties' induced apoptosis more than group I. Generally, the data confirmed that -NH moiety reduced the anticancer activity, while the -CH3 moiety increased the anticancer effect in position two. Our synthesized agents showed promising results. Table 6 Biological assessment of SKBR3 and SKOV3 cell lines. IC 50 : half inhibition concentration- in vitro assessment.

Previously, copper conjugated nimesulide was synthesized and characterized to target the pancreatic cancer cells and the data were promising (Ambike et al., 2007). Moreover, nimesulideloaded nanoparticles were used to treat of prostate cancer and the results showed high cytotoxic activities (Huerta et al., 2015). A series of nimesulide derivatives targeted cellular protein HSP27 and HER2 receptor in ovarian cancer cell lines: OVCAR3, HEY1B and SKOV3. The results indicated that down regulation of HSP27 in SKOV3 cells stabilized HER2 receptor expression through HER2 pathway (Jaragh-Alhadad 2018). In 2020, ovarian cancer (SKOV3 cell line) was targeted with nimesulide analogues conjugated to cholesterol loaded into low density lipoproteins as drug delivery strategy and the results were promising (Alhadad et al., 2020).

In addition, a research study using nimesulide analogues targeting dual proteins HSP27 and HER2 encapsulated into low density lipoprotein as a vehicle to mimic the native low-density lipoproteins metabolic pathway and the research data were potent (Jaragh-Alhadad 2021). Recently, new modifications were implemented on the nimesulide skeleton to target cellular proteins tubulin and HSP27 in breast (SKBR3) and ovarian (SKOV3) cancer cell lines and the cell's growth inhibition was below two and three $\mu \mathrm{M}$, respectively (Jaragh-Alhadad et al., 2021). Furthermore, those research studies showed how nimesulide and its derivatives are potent anticancer agents. 
Table 6. Biological assessment of SKBR3 and SKOV3 cell lines.

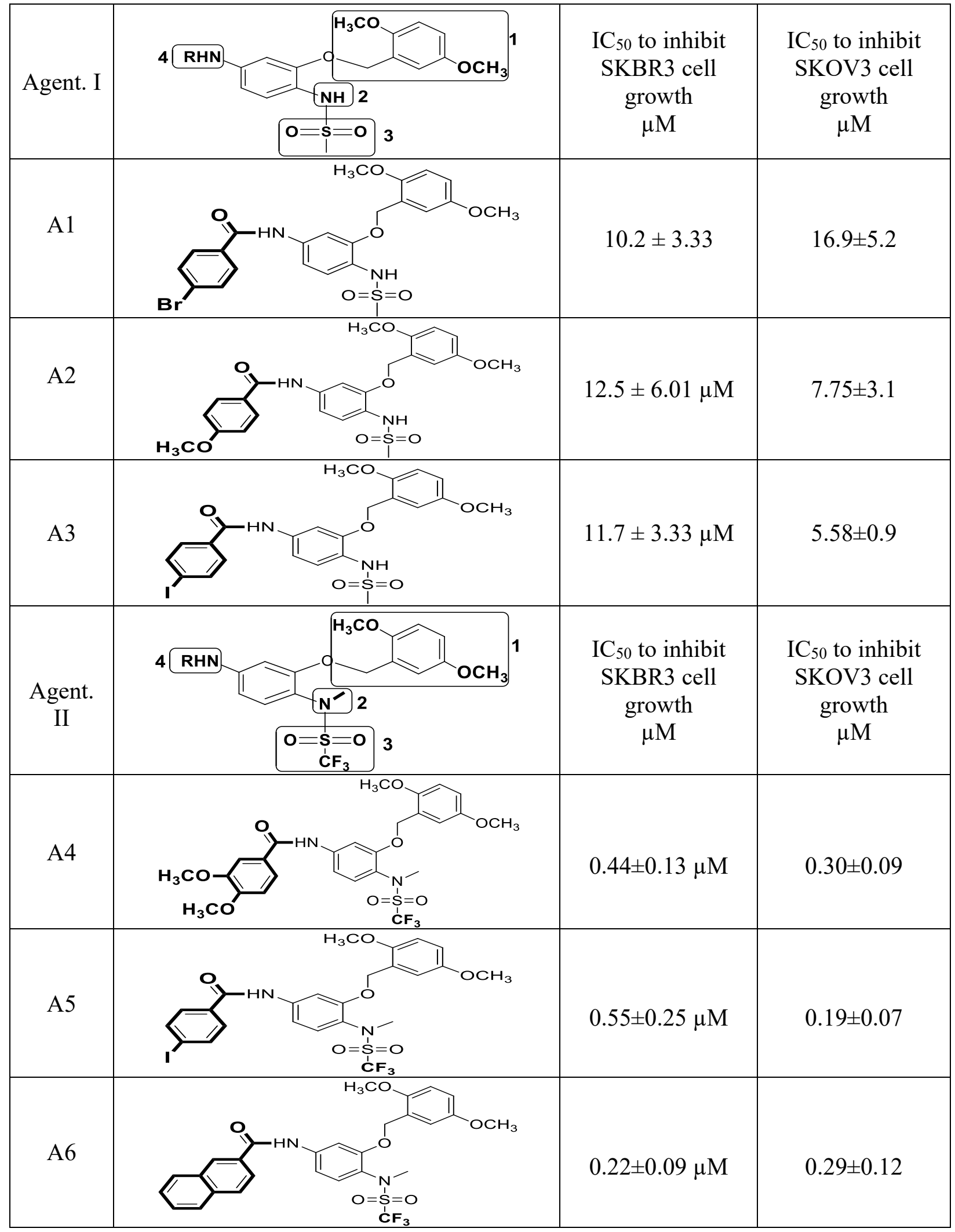

$\mathrm{IC}_{50}$ : half inhibition concentration- in vitro assessment. 


\section{Conclusion}

Nimesulide drug is known for its antiproliferation activity. Therefore, new nimesulide derivatives were designed, synthesized, characterized, and biologically invitro evaluated on SKBR3 and SKOV3 women cancer cell lines. The structure-activity relationship highlights the importance of position two in groups I and II, which must occupy with $-\mathrm{CH}_{3}$ for better biological activity. Shortly, new agents with new modifications on nimesulide skeleton were potent targeting female cancers.

\section{ACKNOWLEDGMENTS}

This project is financially sponsored by grant number SC14/18. We acknowledge the RSPU at Kuwait University with GS01/03, GS01/05, GS02/01, and GS03/08.

\section{Appendix A: Supplementary Material}

Single-crystal data for compound N-(3-((2,5-dimethoxy benzyl) oxy)-4-(methylsulfonamido) phenyl)-4-iodobenzamide, is deposited at Cambridge Crystallographic Data Centre (CCDC) under number 2112456. Additionally, NMR, IR, DSC, and mass figures found in supplementary file.

\section{References}

Al-Azmi, A., Vinodh, M. (2020). Efficient synthesis of Triazolo[4,5-d] pyrimidine-7-carbonitriles and Imidazole-4,5-dicarbonitriles using Triethylorthoalkylates and their structural characterisation by Single-crystal x-ray diffraction, Kuwait Journal of Science, 48 (2): 1-15. https://doi.org/10.48129/kjs.v48i2.9948.

Alhadad, L. J., Harisa, G. H., Alanazi, F. K. (2020). Design and encapsulation of anticancer dual HSP27 and HER2 inhibitor into low density lipoprotein to target ovarian cancer cells. Saudi Pharmaceutical Journal, 28 (4): 387-396. https//: doi.org/10.1016/j.jsps.2020.01.020.

Ambike, V., Adsulem S., Ahmedmm F., Wang, Z., Afrasiabi, Z., Sinn, E., Sarkar, F., Padhey, S. (2007). Copper conjugates of nimesulide Schiff bases targeting VEGF, COX and Bcl-2 in pancreatic cancer cells. Journal of Inorganic Biochemistry, 101 (10): 1517-1524. https://doi.org/10.1016/j.jinorgbio.2007.06.028.

Arya, R., Mallik, M., Lakhotia, S. C. (2007) Heat shock genes integrating cell survival and death. Journal of Biosciences, 32, 595-610. https://doi.org/10.1007/s12038-007-0059-3.

Ferns, G., Shams, S.,Shafi, S. (2006). Heat shock protein 27: its potential role in vascular disease, Int J Exp Pathol. 87 (4): 253-274. https://doi: 10.1111/j.1365-2613.2006.00484.x. 
Garrido, C., Brunet, M., Didelot, C., Zermati, Y., Schmitt, E., Kroemer, G. (2006) Heat Shock Proteins 27 and 70: Anti-Apoptotic Proteins with Tumorigenic Properties, Cell cycle. 5 (22): 2592-2601. https://doi.org/10.4161/cc.5.22.3448.Jackson, J. R., Patrick, D. R., Dar, M. M.,

Huang, P. S. (2007). Targeted anti-mitotic therapies: can we improve on tubulin agents? Nature Reviews Cancer. 7, 107-117. https://doi.org/10.1038/nrc2049.

Huerta, C., Aberturas, M. D. R., Molpeceres, J. (2015). Nimesulide-loaded nanoparticles for the potential coadjuvant treatment of prostate cancer. International Journal of Pharmaceutics, 493 (1-2): 152-160. https://doi.org/10.1016/j.ijpharm.2015.07.027

Jaragh-Alhadad, L. (2018). In-vitro evaluation of HSP27 inhibitors functions through HER2 pathway for ovarian cancer therapy. Transl. Cancer Res., 7 (6): 1510-1517. https://doi: 10.21037/tcr.2018.11.14.

Jaragh-Alhadad, L.; Harisa, G. I.; Alanazi, F. K. (2021). Development of nimesulide analogs as a dual inhibitor targeting tubulin and HSP27 for treatment of female cancers. Journal of Molecular Structure, 1248, 131479. https://doi.org/10.1016/j.molstruc.2021.131479.

Jaragh-Alhadad, L. A. (2021). Encapsulation and in vitro evaluation of low-density lipoprotein with cholesterol conjugated anti HSP27 and HER2 proteins as drug delivery enhancement in ovarian cancer. Biomedical J Sci \& Tech Res. 35 (2): 27497-27504. https//:doi.org/ 10.26717/BJSTR.2021.35.005675.

Jego, G.; Hazoumé, A.; Seigneuric, R.; Garrido, C. (2013). Targeting heat shock proteins in cancer. Cancer Letters, 332 (2): 275-285, https://doi.org/10.1016/j.canlet.2010.10.014.

Kaigorodova, E. v.; Bogatyuk, M. V. (2014). Heat Shock Proteins as Prognostic Markers of Cancer. Current Cancer Drug Targets, $14 \quad$ (8); $\quad$ 713-726. https://doi.org/10.2174/1568009614666140926122846.

Kanthou, C., Tozer, G. M. (2009). Microtubule depolymerizing vascular disrupting agents: novel therapeutic agents for oncology and other pathologies. International Journal of Experimental Pathology, 90 (3): 284-294. https://doi.org/10.1111/j.1365-2613.2009.00651.x.

Kim, L. S.; Kim, J. H. (2011). Heat Shock Protein as Molecular Targets for Breast Cancer Therapeutics. Journal of Breast Cancer, 14 (3): 167-174. DOI: https://doi.org/10.4048/jbc.2011.14.3.167. 
Langdon SP, Rabiasz GJ, Hirst GL, King RJ, Hawkins RA, Smyth JF, Miller WR. (1995). Expression of the heat shock protein HSP27 in human ovarian cancer. Clin Cancer Res. 1(12):1603-9. PMID: 9815962.

Lamoureux, F.; Thomas, C.; Yin, M-J.; Fazli, l.; Zoubeidi, A. et al. (2014). Suppression of Heat Shock Protein 27 Using OGX-427 Induces Endoplasmic Reticulum Stress and Potentiates Heat Shock Protein 90 Inhibitors to Delay Castrate-resistant Prostate Cancer. European Urology, 66: (1), 145-155. https://doi.org/10.1016/j.eururo.2013.12.019.

Li, Q., and Sham, H. L. (2002). Discovery and development of antimitotic agents that inhibit tubulin polymerization for the treatment of cancer. Expert Opinion on Therapeutic Patents, 12: (11), 1663-1702. https://doi.org/10.1517/13543776.12.11.1663.

Lianos, G. D.; Alexiou, G. A.; Mangano, A.; Mangano, A.; Rausei, s. et al. (2015). The role of heat shock proteins in cancer. Cancer letters, 360 (2): 114-118. https://doi.org/10.1016/j.canlet.2015.02.026.

Lyseng-Williamson, K. A., Fenton, C. (2005). Docetaxel: a review of its use in metastatic breast cancer. Drugs, 65 (17): 2513-31. https//:doi: 10.2165/00003495-200565170-00007.

Parker, A. L.; Kavallaris, M.; McCarroll, J. A. (2014). Microtubules and their role in cellular stress in cancer. Front. Oncol., https://doi.org/10.3389/fonc.2014.00153.

Paul, C., Simon, S., Gibert, B., virot, S., Manero, F., Ariigo, A. p. (2010). Dynamic processes that reflect anti-apoptotic strategies set up by HspB1 (Hsp27). Experimental Cell Research, 316 (9): 1535-1552. https://doi.org/10.1016/j.yexcr.2010.03.006.

Pavan, S., Musiani, D., Torchiaro, E., Migliadi, G., Gai, M., Di Cunto, F., Erriquez, J., Olivero, M., Di Renzo, M. F. (2013). HSP27 is required for invasion and metastasis triggered by hepatocyte growth factor. International Journal of cancer, 134 (6): 1289-1299. https://doi.org/10.1002/ijc.28464.

Philippa, C. and Daniel, P. (2013). Tubulin-Targeted Agents Including Docetaxel and Cabazitaxel. The Cancer Journal, 19: (1), 59-. https://doi: 10.1097/PPO.0b013e3182828d38.

Roque, D. M.; Buza, N.; Glasgow, M.; Bellone, S.; Bortolomai, I. et al. (2014). Class III $\beta$ tubulin overexpression within the tumor microenvironment is a prognostic biomarker for poor overall survival in ovarian cancer patients treated with neoadjuvant carboplatin/paclitaxel. Clin Exp Metastasis, 31: (1): 101-110. https:// doi: 10.1007/s10585-013-9614-5. 
Song, Y.; Liu, Z.; Mao, H.; Hemley, R. (2005). High-pressure vibrational spectroscopy of sulfur dioxide. J. Chem. Phys. 122, 174511. https://doi.org/10.1063/1.1883405.

Vargas-Roig, L. M.; Gago, F. E.; Tello, O.; Aznar, J. C.; Ciocca, D. R. (1998). Heat shock protein expression and drug resistance in breast cancer patients treated with induced chemotherapy. Int. J. Cancer (Pred. Oncol.). 79, 468-475 (1998).v https://doi.org/10.1002/(SICI)1097-0215(19981023)79:5<468::AID-IJC4>3.0.CO;2-Z.

Venugopal, A., Sundaramoorthy, K., Vellingiri, B. (2019). Therapeutic potential of Hsp27 in neurological diseases. Egypt J Med Hum Genet 20, 21. https://oi.org/10.1186/s43042-019-00234.

Vidyasagar, A.; Wilson, N. A.; and Djamali, A. (2012). Heat shock protein 27 (HSP27): a biomarker of disease and therapeutic target. Fibrogenesis \& Tissue Repair, 5 (7): 1-7. https://doi.org/10.1186/1755-1536-5-7.

Voll, E. A., Ogden,I. M., Pavese, J. M., Huang, X., Xu, L., Jovanovic, B. D., Bergan, R. C. (2014). Heat shock protein 27 regulates human prostate cancer cell motility and metastatic progression. Oncotarget, 5 (9): 2648-2663. https: doi: 10.18632/oncotarget.1917.

Zhao, M.; Shen, F.; Yin, Y. X.; Yang, Y. Y.; Xiang D. J. (2012). Increased Expression of Heat Shock Protein 27 Correlates with Peritoneal Metastasis in Epithelial Ovarian Cancer. Reproductive Sciences, 19, 748-753. https://doi.org/10.1177/1933719111432875.

Zoubeidi, A.; Gleave, M. (2012). Small heat shock proteins in cancer therapy and prognosis. The International Journal of Biochemistry \& Cell Biology, 44, (10), 1646-1656. https://doi.org/10.1016/j.biocel.2012.04.010.

Submitted: $\quad 14 / 10 / 2021$

Revised: $\quad 05 / 12 / 2021$

Accepted: $\quad 15 / 12 / 2021$

DOI: $\quad 10.48129 /$ kjs. 16735 